\title{
PENERAPAN METODE ANALYTICAL HIERARCHY PROCESS DAN SIMPLE ADDITIVE WEIGHTING UNTUK PEMILIHAN KARYAWAN TERBAIK SETIAP JABATAN PADA PT. WAHANA PIRANTI TEKNOLOGI
}

\author{
Fitra Rahmatullah $^{1)}$, Humisar Hasugian ${ }^{2)}$ \\ ${ }^{1}$ Sistem Informasi, Fakultas Teknologi Informasi, Universitas Budi Luhur \\ ${ }^{1,2} \mathrm{Jl}$. Raya Ciledug, Petukangan Utara, Kebayoran Lama, Jakarta Selatan 12260 \\ E-mail : fitra.rahmatullah16@gmail.com ${ }^{1}$, humisar.hasugian@budiluhur.ac.id ${ }^{2}$
}

\begin{abstract}
Abstrak
Karyawan adalah Sumber Daya Manusia (SDM) yang dimanfaatkan dalam mencapai target yang ditetapkan. PT. Wahana Piranti Teknologi merupakan perusahaan yang bergerak dibidang distributor IT, yang sedang berupaya membidik dan menangkap Pasar Indonesia. Adanya kinerja karyawan yang tidak stabil, sangat mempengaruhi hasil yang ingin dicapai PT. Wahana Piranti Teknologi. Salah satu solusi dalam meningkatkan kinerja karyawan yaitu mengadakan sistem pemilihan karyawan terbaik, yang dapat memberi motivasi dan dorongan dalam meningkatkan kinerja karyawan. Masalah yang terdapat dalam mengadakan sistem pemilihan karyawan terbaik pada PT. Wahana Piranti Teknologi adalah belum adanya kriteria, bobot keriteria beserta metode dalam pemilihan karyawan terbaik, sehingga sulit untuk menentukan karyawan terbaik yang tepat dan akurat. Penelitian ini bertujuan untuk membangun sistem penunjang keputusan pemilihan karyawan terbaik setiap jabatan dengan menerapkan metode Analytical Hierarchy Process (AHP) dan Simple Additive Weighting (SAW). Penghitungan bobot kriteria pada jabatan technical yang dihasilkan dalam penelitian ini adalah Kriteria Lama Bekerja 4,1\%, Kriteria Presentasi 5,58\%, Kriteria Project 58,76\%, Kriteria Sertifikasi 21,03\%, dan Kriteria Training 10,53\%, dengan hasil uji Consistency Ratio (CR) sebesar 0,0745. Sistem penunjang keputusan ini dapat memberikan informasi dengan lebih jelas dan cepat sehingga dapat memudahkan proses pemilihan karyawan terbaik pada PT. Wahana Piranti Teknologi.
\end{abstract}

Kata kunci: Sistem Penunjang Keputusan, Karyawan, AHP, SAW

\section{PENDAHULUAN}

Karyawan adalah bagian dari perusahaan yang harus dijaga dan dimanfaatkan dengan baik. Usaha yang maksimal menggambarkan bahwa yang dihasilkan oleh setiap karyawan memenuhi apa yang diinginkan oleh perusahaan [1]. Sumber Daya Manusia (SDM) adalah sebuah pendukung peningkatan produktivitas kinerja sebuah perusahaan. Oleh sebab itu sumber daya manusia yang baik menggambarkan kinerja yang baik pula, dengan adanya penilaian kinerja dapat dilihat prestasi dari setiap karyawan, hal tersebut dapat dimanfaatkan oleh perusahaan sebagai pertimbangan untuk melakukan pemilihan karyawan terbaik [2]. PT. Wahana Piranti Teknologi yang ingin melakukan pemilihan karyawan terbaik guna menambah motivasi dan dorongan dalam meningkatkan kinerja karyawannya, tengah memiliki kendala yaitu, belum adanya penetapan kriteria karyawan terbaik yang merupaka ukuran yang menjadi dasar penilaian atau penetapan karyawan terbaik, serta belum memiliki bobot pada setiap kriteria tersebut sehingga sulit untuk melakukan pemilihan karyawan terbaik, dan belum adanya metode dalam melakukan pemilihan karyawa terbaik yang menyebabkan hasil pemilihan tidak tepat dan tidak akurat. Penelitian ini bertujuan untuk membangun sistem penunjang keputusan pemilihan karyawan terbaik menggunakan metode Analytical Hierarchy Process (AHP) dan Simple Additive Weighting (SAW). AHP adalah sebuah metode yang menggunakan hirarki fungsional dalam penerapannya, sehingga himpunan kestuan sebuah masalah dapat dipecah ke dalam kelompoknya, yang selanjutnya dijadikan suatu bentuk hirarki [3]. SAW adalah metode penjumlahan terbobot yang mencari penjumlahan terbobot dari rating kinerja setiap alternatif pada semua kriteria [4]. SAW memiliki kemampuan dalam melakukan penilaian yang lebih akurat, karena didasarkan pada nilai kriteria dan bobot preferensi yang sudah ditentukan [5] Penelitian pada sistem penunjang keputusan pemilihan karyawan terbaik dengan metode AHP telah dilakukan [1], metode SAW oleh [2] dan [6]. Dimana penelitian diatas memiliki kriteria yang sama pada setiap jabatan. Penelitian yang penulis lakukan yakni menggabungkan metode AHP dan SAW, serta kriteria-kriteria yang ada pada suatu jabatan berbeda dengan jabatan yang lainnya. 


\section{METODE PENELITIAN}

\subsection{Tahapan Penelitian}

Ada beberapa tahapan yang penulis lakukan dalam penelitian ini, seperti pada gambar 1.

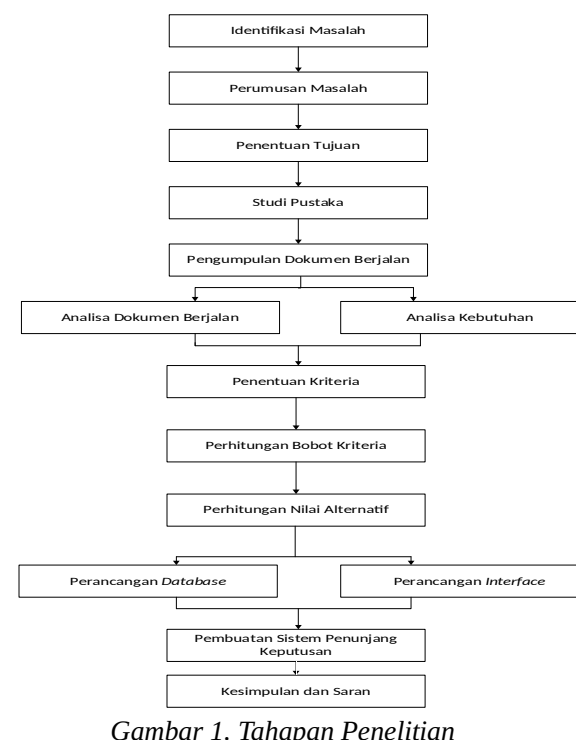

Pada gambar diatas dapat dilihat tahap-tahap penelitian yang penulis lakukan yaitu :

1) Identifikaasi Masalah

Pada tahap identifikasi masalah penulis melakukan wawancara dengan manajer PT. Wahana Piranti Teknologi membahas tentang sistem pemilihan karyawan terbaik, hingga menemukan kendala yang terdapat dalam sistem pemilihan karyawan terbaik.

2) Perumusan Masalah

Masalah atau kendala yang ditemukan di tahap pertama, selanjutnya penulis melakukan perumusan pada masalah tersebut dengan menggunakan fishbone diagram.

3) Penentuan Tujuan

Tahap ini merupakan tahap untuk menentukan tujuan penelitian dan juga menentukan solusi dari masalah yang terdapat pada tahap sebelumnya.

4) Studi Pustaka

Studi Pustaka merupakan tahap dimana penulis mencari referensi berupa buku dan jurnal, guna memperkuat argumentasi yang berkaitan dengan penelitian.

5) Pengumpulan Dokumen Berjalan

Tahap ini merupakan tahap pengumpulan dokumen yang diperlukan pada PT. Wahana Piranti Teknologi dalam membangun sistem penunjang keputusan pemilihan karyawan terbaik.

6) Analisa Dokumen Berjalan dan Analisa Kebutuhan

Pada tahap ini penulis melakukan analisa pada dokumen yang telah didapatkan di tahap sebelumnya, sehingga mendapatkan informasi yang berguna dalam mencapai tujuan. Serta penulis menganalisa kebutuhan dalam sistem penunjang keputusan karyawan terbaik pada PT. Wahana Piranti Teknologi dengan menggunakan usecase diagram.

7) Penentuan Kriteria

Pada tahap ini manajer PT. Wahana Piranti Teknologi melakukan penetapan kriteria pemilihan karyawan terbiak, kemudian penulis melakukan penggolongan kriteria benefit dan kriteria cost.

8) Perhitungan Bobot Kriteria

Perhitungan bobot kriteria penulis lakukan dengan menerapkan metode AHP terhadap nilai perbandingan antar kriteria. Dimana nilai perbandingan kriteria ditentukan oleh manajer PT. Wahana Piranti Teknologi dengan mengisi kuesioner yang penulis berikan.

9) Perhitungan Nilai Alternatif

Tahap ini merupakan tahap pengolahan nilai alternatif pada semua kriteria dengan menerapkan metode SAW. Sehingga menghasilkan nilai akhir dan rangking setiap alternatif.

10) Perancangan Database dan Perancangan Interface

Tahap ini merupakan tahap pembuatan rancangan database dengan menggunakan Entity Relationship Diagram (ERD). Kemudian penulis membuat rancangan layar berdasarkan usecase diagram.

11) Pembuatan Sistem Penunjang Keputusan

Pada tahapan ini, semua hasil dari tahapantahapan sebelumnya kemudian diimplementasikan untuk membuat sistem penunjang keputusan pemilihan karyawan terbaik sesuai dengan kebutuhan dan tujuan yang telah ditetapkan.

12) Kesimpulan dan Saran

Tahap ini merupakan tahap pembuatan kesimpulan dari penelitian dan pembuatan saran mengenai sistem penunjang keputusan pemilihan karyawan terbaik yang telah dibuat.

\subsection{Teknik Analisa Data}

Penelitian ini menggunakan analisis deskriptif, Analitycal Hierarchy Process (AHP), dan Simple Additive Weighting (SAW). Analisa deskriptif digunakan untuk menggambarkan keadaan sekarang dalam bentuk rangkuman hasil survey, sedangkan AHP dan SAW untuk menentukan karyawan terbaik tiap jabatan pada PT. Wahana Piranti Teknologi.

\section{HASIL DAN PEMBAHASAN}

\subsection{Profil Organisasi}

PT. Wahana Piranti Teknologi merupakan perusahaan distributor IT yang telah berdiri sejak tahun 2013. PT. Wahana Piranti Teknologi didirikan 
dengan maksud untuk memberitahukan kepada semua orang, terutama mitra bisnisnya bahwa teknologi itu tidak mahal. Adapun visi dan misi PT. Wahan Piranti Teknologi adalah "Membidik dan menangkap pasar Indonesia dengan memberikan solusi terdepan dan dukungan terus menerus kepada mitra bisnis - menegakkan bahwa 'Teknologi tidak mahal'”. PT. Wahana Piranti Teknologi telah memiliki banyak mitra bisnis baik itu dari dalam negeri maupun luar negeri. Adapun brand produk yang mereka salurkan diantaranya yaitu Ruijie Network, ALTAI Super Wifi, Sonic Wall, Quest Software, dan lainnya.

\subsection{Model Metode Analytical Hierarchy Process (AHP)}

Pada penelitian ini metode AHP dimanfaatkan dalam mendapatkan bobot setiap kriteria. Struktur hierarki pemilihan karyawan terbaik pada PT. Wahana Piranti ada dua yakni seperti gambar 2.

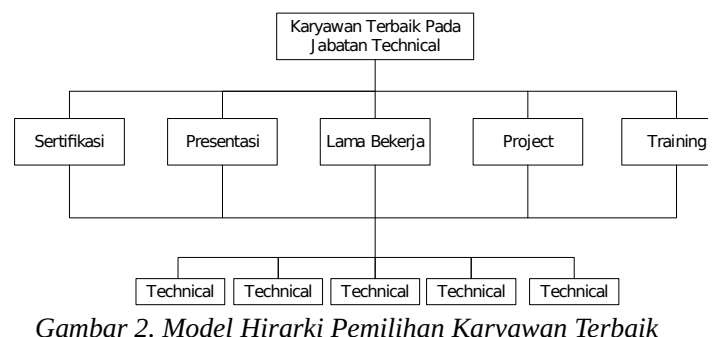

Pada Gambar 2 yang merupakan struktur hierarki pada jabatan technical dapat dilihat, yang menjadi alterntaif yaitu technical, sedangkan kriterianya yaitu Sertifikasi, Presentasi, Lama Bekerja, Project, serta Training, dan tujuan pada hierarki tersebut adalah menentukan karyawan terbaik pada jabatan technical.

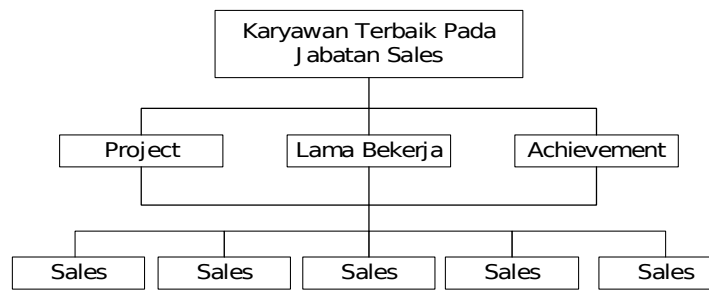

Gambar 3. Model Hirarki Pemilihan Karyawan Terbaik

Pada Gambar 3 yang merupakan struktur hierarki pada jabatan sales dapat dilihat yang menjadi alterntaif yaitu sales, sedangkan kriterianya yaitu Project, Lama Bekerja, serta Achievement, dan tujuan pada hierarki tersebut adalah menentuka karyawan terbaik pada jabatan sales.

\subsection{Pengolahan data dengan metode \\ Analytical Hierarchy Process (AHP).}

Setelah melakukan penetapan kriteria pada setiap jabatan oleh manajar PT. Wahana Piranti Teknologi, selanjutnya manajer diminta untuk melakukan perbandingan pada kriteria-kriteria tersebut dengan mengisi kuesioner dari penulis. Dimana nilai perbandingan tersebut akan diolah dengan metode AHP untuk mendapatkan bobot setiap kriteria. Adapun nilai perbandingan antar kriteria pada jabatan technical adalah seperti pada tabel 1, dan nilai perbandingan antar kriteria pada jabatan sales adalah seperti pada tabel 2.

Tabel 1. Tabel Matriks Nilai Perbandingan Kriteria Pada Jabatan Technical

\begin{tabular}{lccccc}
\hline Kriteria & $\begin{array}{c}\text { Lama } \\
\text { Bekerja }\end{array}$ & & & & \\
\hline Lama Bekerja & $1 / 1$ & $1 / 2$ & $1 / 7$ & $1 / 5$ & $1 / 3$ \\
Presentasi & $2 / 1$ & $1 / 1$ & $1 / 7$ & $1 / 4$ & $1 / 3$ \\
Project & $7 / 1$ & $7 / 1$ & $1 / 1$ & $5 / 1$ & $7 / 1$ \\
Sertifikasi & $5 / 1$ & $4 / 1$ & $1 / 5$ & $1 / 1$ & $3 / 1$ \\
Trainig & $3 / 1$ & $3 / 1$ & $1 / 7$ & $1 / 3$ & $1 / 1$ \\
\hline
\end{tabular}

Tabel 2. Tabel Matriks Nilai Perbandingan Kriteria Pada Jabatan Sales

\begin{tabular}{lccc}
\hline Kriteria & \multicolumn{2}{c}{ Lama Bekerja Project } & Achievement \\
\hline Lama Bekerja & $1 / 1$ & $1 / 7$ & $1 / 8$ \\
Project & $7 / 1$ & $1 / 1$ & $1 / 3$ \\
Achievement & $8 / 1$ & $3 / 1$ & $1 / 1$ \\
\hline
\end{tabular}

\subsection{Pengujian Metode Analytical Hierarchy Process (AHP)}

Pengujian AHP didasarkan pada nilai Consistency Ratio (CR), dimana nilai CR hanya boleh bernilai $\leq 10 \%$.

Tahap pertama dalam melakukan pengujian AHP adalah dengan mencari nilai Consistency Index (CI) dengan menggunakan rumus (1) .

$$
C I=\frac{(\pi-n)}{n-1} n=\text { Banyaknya kriteria }
$$

Nilai CI pada jabatan technical adalah $C I=\frac{(5.3999-5)}{5-1}=0.0835$

Sedangkan nilai CI pada jabatan sales adalah $C I=\frac{(3.1076-3)}{3-1}=0.0538$

Setelah mendapatkan nilai CI selanjutnya mencari nilai Consistency Ratio (CR) dengan rumus (2).

$$
C R=\frac{C I}{I R} \text { Dimana nilai IR didapatkan dari tabel Oarkridge }
$$




$$
C R=\frac{0.0835}{1.12}=0,0745
$$

Sedangkan nilai CR pada jabatan sales adalah $C R=\frac{0.0538}{0.58}=0,0928$

Bobot setiap kriteria yang diperoleh dari penerapan metode AHP pada penelitian ini yaitu seperti tabel 3.

Tabel 3. Persentase Bobot Kriteria

\begin{tabular}{lll}
\hline Jabatan & Nama Kriteria & Bobot \\
\hline Technical & Lama Bekerja & $4,1 \%$ \\
& Presentasi & $5,58 \%$ \\
& Project & $58,76 \%$ \\
Sertifikasi & $21,03 \%$ \\
Training & $10,53 \%$ \\
Toles & Lamal & $100 \%$ \\
& Project & $5,47 \%$ \\
& Achievement & $29,33 \%$ \\
& Total & $105,20 \%$ \\
\hline
\end{tabular}

\subsection{Model Keputusan Dengan Metode}

Simple Additive Weighting (SAW)

Metode SAW dimanfaatkan dalam menentukan rangking setiap karyawan. Langkah pertama dalam penerapan metode SAW adalah melakukan normalisasi dengan rumus (3).

$$
r_{i j}=\left\{\begin{array}{l}
\frac{X_{i j}}{\operatorname{Max} X_{i j}} \text { Jika jadalah atribut keuntungan }(\text { benefit }) \\
\frac{\operatorname{Min} X_{i j}}{X_{i j}} \text { Jika jadalah atribut biaya }(\text { cost })
\end{array}\right.
$$

$$
i=\text { alternatif pada kolomn }(1,2,3, \ldots, n)
$$

$j=$ kriteria pada barisn $(1,2,3, \ldots, n)$

$r_{i j}=$ nilai rating kinerjaternormalisasi

$X_{i j}=$ nilai atribut yang dimiliki dari setiap kriteria

Max $X_{i j}=$ nilai terbesar alternatif dari setiap kriteriai

$\operatorname{Min} X_{i j}=$ nilai terkecilalternatif darisetiap kriteriai

Pada penelitian ini mengambil 5 alterntif setiap jabatan sebagai sampel dalam penerapan metode SAW. Adapun alternatif beserta nilainya terhadap tiap-tiap kriteria pada jabatan technical yaitu seperti pada tabel 4, pada jabatan sales yaitu seperti tabel 5 .

Tabel 4. Data Nilai Alternatif Per Kriteria Pada Jabatan Technical

\begin{tabular}{lrlllll}
\hline Nama Alternatif & Kriteria & & & \\
\cline { 2 - 7 } & $\begin{array}{l}\text { Lama } \\
\text { Bekerja( } \\
\text { Hari) }\end{array}$ & $\begin{array}{l}\text { Present } \\
\text { asi }\end{array}$ & $\begin{array}{l}\text { Proj } \\
\text { ect }\end{array}$ & $\begin{array}{l}\text { Sertifik } \\
\text { asi }\end{array}$ & $\begin{array}{l}\text { Traini } \\
\text { ng }\end{array}$ \\
\hline Tutur Dwiputro & & & & & & \\
Surendi & 1282 & 4 & 5 & 3 & 4 \\
Ahmad Reza & & & & & \\
Siregar & 588 & 8 & 2 & 3 & 2 \\
Erwin Mustofa & 1129 & 8 & 3 & 3 & 4 \\
Ari Agus Triyono & 1043 & 4 & 8 & 5 & 3 \\
Jakaria & 1043 & 8 & 2 & 2 & 3 \\
\hline
\end{tabular}

Tabel 5. Data Nilai Alternatif Per Kriteria Pada Jabatan Sales

\begin{tabular}{lccr}
\hline Nama Alternatif Kriteria & & \\
\cline { 2 - 4 } & $\begin{array}{l}\text { Lama Bekerja } \\
\text { (Hari) }\end{array}$ & Project & \multicolumn{1}{l}{$\begin{array}{l}\text { Achievement } \\
\text { (Rp) }\end{array}$} \\
\hline Meirina Hidayat & 511 & 46 & Rp 1,083,837,107 \\
Andreas Tarigan & 294 & 18 & Rp 129,885,605 \\
Indah Irawan & 572 & 14 & Rp 165,556,568 \\
Diko Ariyawika & 710 & 1 & Rp 7,678,202 \\
Denny Sumarlin & 517 & 67 & Rp 561,075,456 \\
\hline
\end{tabular}

Hasil normalisasi terhadap tabel nilai alternatif pada jabatan technical yaitu seperti tabel 6, dan pada jabatan sales yaitu seperti tabel 7 .

Tabel 6. Nilai Matriks Normalisasi Kriteria Pada Jabatan Technical

\begin{tabular}{lccccc}
\hline Nama & Kriteria & & & & \\
\cline { 2 - 6 } & $\begin{array}{l}\text { Lama } \\
\text { Bekerja }\end{array}$ & $\begin{array}{l}\text { Present } \\
\text { asi }\end{array}$ & $\begin{array}{l}\text { Sertifik } \\
\text { asi }\end{array}$ & $\begin{array}{l}\text { Trainin } \\
\text { groject }\end{array}$ \\
\hline $\begin{array}{l}\text { Tutur } \\
\text { Dwiputro }\end{array}$ & & & & & \\
$\begin{array}{l}\text { Surendi } \\
\text { Ahmad Reza }\end{array}$ & 1 & 0,5 & 0,625 & 0,6 & 1 \\
$\begin{array}{l}\text { Siregar } \\
\text { Erwin }\end{array}$ & 0,4587 & 1 & 0,25 & 0,6 & 0,5 \\
$\begin{array}{l}\text { Mustofa } \\
\text { Ari Agus }\end{array}$ & 0,8807 & 1 & 0,375 & 0,6 & 1 \\
$\begin{array}{l}\text { Triyono } \\
\text { Jakaria }\end{array}$ & 0,8136 & 0,5 & 1 & 1 & 0,75 \\
\hline Bobot & 0,8136 & 1 & 0,25 & 0,4 & 0,75 \\
\hline
\end{tabular}

Tabel 7. Nilai Matriks Normalisasi Kriteria Pada Jabatan Sales

\begin{tabular}{lccc}
\hline Nama Alternatif & \multicolumn{3}{l}{ Kriteria } \\
\cline { 2 - 4 } & Lama Bekerja & Project & Achievement \\
\hline Meirina Hidayat & 0,7197 & 0,6866 & 1 \\
Andreas Tarigan & 0,4140 & 0,2687 & 0,1198 \\
Indah Irawan & 0,8056 & 0,2090 & 0,1528 \\
Diko Ariyawika & 1 & 0,0149 & 0,0071 \\
Denny Sumarlin & 0,7282 & 1 & 0,5177 \\
Bobot & 0,0547 & 0,2933 & 0,6520 \\
\hline
\end{tabular}

Setelah mendapatkan nilai normalisasi, tahap selanjutnya yaitu melakukan proses preferensi (Vi) atau perangkingan dengan menggunakan rumus (4).

$$
V_{i}=\sum_{j=1}^{n} w_{j} r_{i j}
$$

Ket :

$V i=$ Rangking untuk setiap alternatif

Wj=Nilai bobot dari kriteria

Rij= Nilai alternatif ternormalisasi

Berikut merupakan perhitungan perangkingan pada jabatan technical :

1) Tutur Dwiputro Surendi $=$

$\{(1 \times 0,0410)+(0,5 \times 0,0558)+(0,625 \times 0,5876)+(0$ $, 6 \times 0,2103)+(1 \times 0,1053)\}$

$$
=0,66763
$$


$=0,6676$

2) Ahmad Reza Siregar $=$

$\{(0,4587 \times 0,0410)+(1 \times 0,0558)+(0,25 \times 0,5876)+$

$(0,6 \times 0,2103)+(0,5 \times 0,1053)\}$

$=0,4003367$

$=0,4003$

3) Erwin Mustofa $=$ $\{(0,8807 \times 0,0410)+(1 \times 0,0558)+$

$(0,375 \times 0,5876)$

$+(0,6 \times 0,2103)+(1 \times 0,1053)\}$

$=0,5437387$

$=0,5437$

4) Ari Agus Triyono $=$

$\{(0,8136 \times 0,0410)+(0,5 \times 0,0558)+(1 \times 0,5876)$

$+(1 \times 0,2103)+(0,75 \times 0,1053)\}$

$=0,9381326$

$=0,9381$

5) Jakaria $=$

$\{(0,8136 \times 0,0410)+(1 \times 0,0558)+(0,25 \times$

$0,5876)+(0,4 \times 0,2103)+(0,75 \times 0,1053)\}$

$=0,3991526$

$=0,3992$

Sedangkan perhitungan perangkingan pada jabatan sales_adalah sebagai berikut :

1) Meirina Hidayat $=$

$\{(0,7197 \times 0,0547)+(0,6866 \times 0,2933)+(1 \times$

$0,6520)\}$

$=0,89274737$

$=0,8928$

2) Andreas Tarigan $=$

$\{(0,4140 \times 0,0547)+(0,2687 \times 0,2933)+(0,1198 \times$ $0,6520)\}$

$=0,17956511$

$=0,1796$

3) Indah Irawan= $0,6520)\}$

$\{(0,8056 \times 0,0547)+(0,2090 \times 0,2933)+(0,1528 \times$

$=0,20499162$

$=0,2050$

4) Diko Ariyawika =

$\{(1 \times 0,0547)+(0,0149 \times 0,2933)+(0,0071 \times$

$0,6520)\}$

$=0,0639937$

$=0,0637$

5) Denny Sumarlin = $0,6520)\}$

$\{(0,7282 \times 0,0547)+(1 \times 0,2933)+(0,5177 \times$

$=0,67067294$
$=0,6707$

Dari perhitungan perangkingan di atas dapat ditetapkan ranking pada karyawan berdasarkan nilai akhir dari perhitungan tersebut, ranking pada jabatan technical adalah seperti pada tabel 8, dan pada jabatan sales adalah seperti pada tabel 9.

Tabel 8. Nilai Akhir Alternatif Pada Jabatan Technical

\begin{tabular}{llc}
\hline Rank & Nama Karyawan & Nilai Akhir \\
\hline 1 & Ari Agus Triyono & 0,9381 \\
2 & Tutur Dwiputro Surendi & 0,6676 \\
3 & Erwin Mustofa & 0,5437 \\
4 & Ahmad Reza Siregar & 0,4003 \\
5 & Jakaria & 0,3992 \\
\hline
\end{tabular}

Tabel 9. Nilai Akhir Alternatif Pada Jabatan Sales

\begin{tabular}{lll}
\hline Rank & Nama Karyawan & Nilai Akhir \\
\hline 1 & Meirina Hidayat & 0,8928 \\
2 & Denny Sumarlin & 0,6707 \\
3 & Indah Irawan & 0,2050 \\
4 & Andreas Tarigan & 0,1796 \\
5 & Diko Ariyawika & 0,0637 \\
\hline
\end{tabular}

\subsection{Model Basis Data}

Model basis data adalah tahapan pemodelan dan pembuatan database yang akan diterapkan pada sistem. Tahapan dalam pemodelan basis data yaitu membuat Entity Relationship Diagram (ERD) seperti pada gambar 4, dimana ERD tersebut terdapat 4 (empat) entitas yaitu entitas kriteria, entitas jabatan, entitas karyawan, dan satu entitas lemah (week entity) yaitu entitas hasil. Pada entitas terdapat atribut dengan tanda (*) yang merupakan atribut primary key.

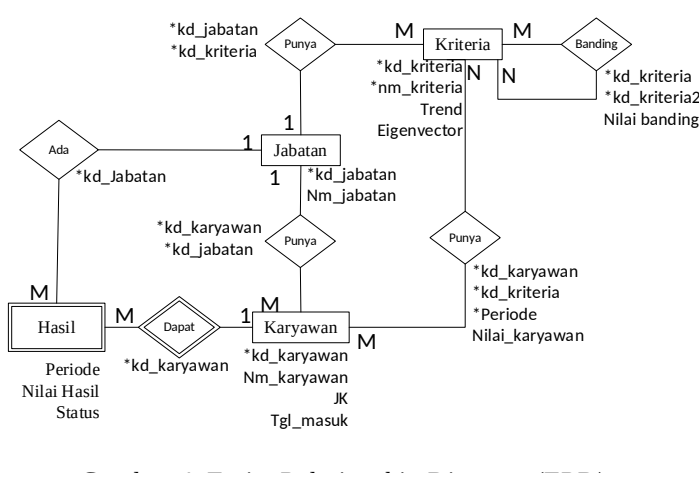

Tahap selanjutnya yaitu membuat transformasi ERD seperti pada gambar 5, dimana entitas karyawan dan relasi antara entitas karyawan dan entitas jabatan digabungkan dalam satu kotak karena relasi akan digabungkan dengan kardinalitas $\mathrm{M}$. Sedangkan entitas karyawan, relasi antara entitas karyawan dan entitas kriteria, dan entitisa kriteria berada dalam satu kotak tersendiri, kerena kardinalitas antara karyawan dan kriteria yaitu M:M. 


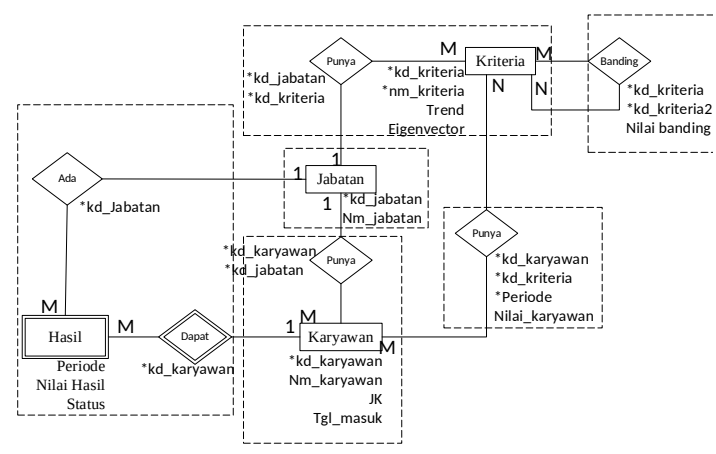

Tahap yang ketiga yaitu membuat LRS seperti gambar 6, dimana entitas dan atribut berada dalam sebuah kotak. Pada LRS tersebut terdapat entitas yang merupkan entitas hasil hasil dari kardinalitas M:M, yaitu entitas alternatif dan entitas banding kriteria.

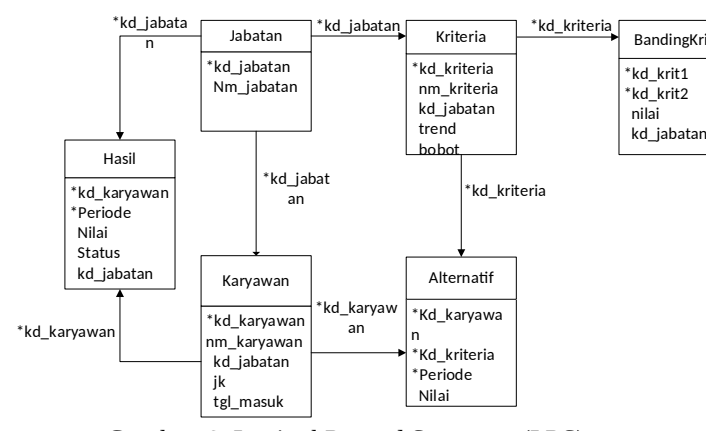

\subsection{Usecase Diagram}

Diagram usecase adalah sebuah pemodelan yang menggambarkan perilaku dari sistem. Usecase yang terdapat pada penilitian ini adalah sebagai berikut :

Pertama yaitu usecase diagram input seperti pada gambar 7, yang menjadi aktor pada usecase diagram input yaitu manjer, dan terdapat 3(tiga) usecase yaitu entri data jabatan, entri data karyawan, dan entri data kriteria.

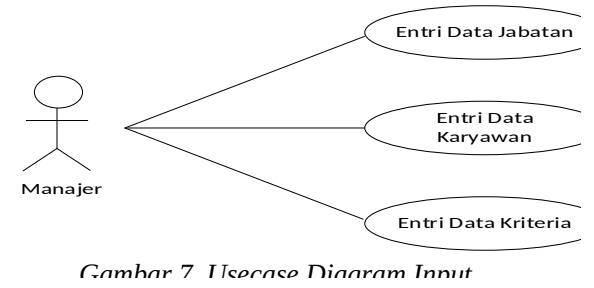

Kedua yaitu Usecase diagram process seperti pada gambar 8, yang menjadi aktor pada usecase diagram process yaitu manjer, dan terdapat 4(empat) usecase yaitu entri nilai perbanidngan kriteria, entri nilai alternatif, perhitungan nilai alternatif, dan entri hasil keputusan.

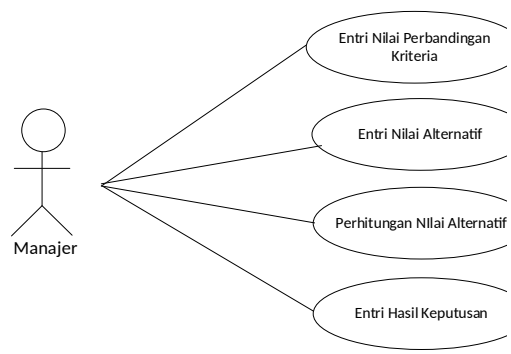

Ketiga yaitu Usecase diagram output seperti gambar 9, yang menjadi aktor pada usecase diagram output yaitu manjer, dan terdapat 3(tiga) usecase yaitu setak bukti hasil keputusan, cetak laporan rangking karyawan, dan cetak laporan kinerja karyawan.

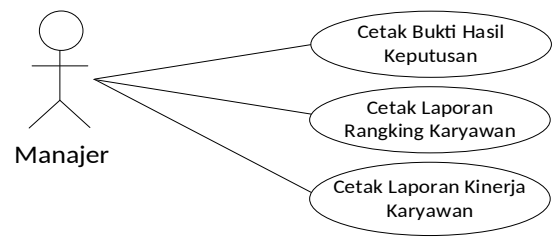

\subsection{Rancangan Layar}

Rancangan Layar adalah rancangan interface yang terdapat pada sistem. Pada penelitian ini terdapat 10 (sepuluh) rancangan layar yakni berdasarkan pada usecase yang terdapat pada usecase diagram, 4 (empat) diantaranya yaitu sebagai berikut :

1) Rancangan Layar Entri Data Karyawan

Pada rancangan layar entri data karyawan seperti gambar 10, terdapat kode karyawan, jabatan, nama karyawan, jenis kelamin, dan tanggal masuk yang harus diisi user. Fungsi yang terdapat pada rancangan layar entri data karyawan yaitu simpan, ubah, hapus, dan batal.

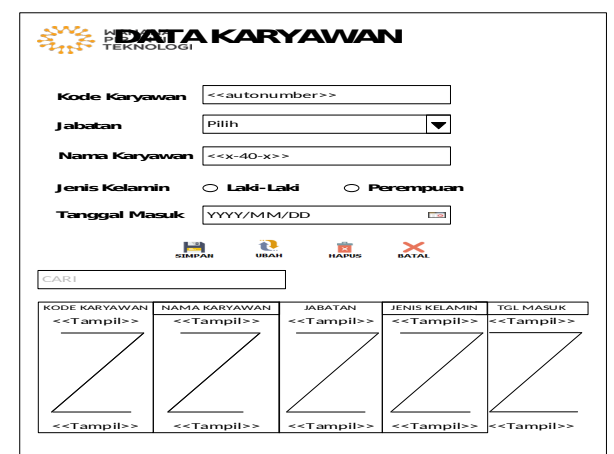


2) Rancangan Layar Entri Nilai Perbandingan Kriteria

Pada rancangan layar entri nilai perbandingan kriteria seperti pada gambar 11, terdapat combo box jabatan, combo box kriteria1, combo box kriteria2, combo box nilai perbandingan, tabel matiks normalisasi besrta eigenvector, dan tabel bobot kriteria. Fungsi yang terdapat pada rancangan layar entri nilai perbandingan kriteria yaitu simpan nilai perbandinga, ubah nilai perbandingan,dan simpan bobot kriteria.

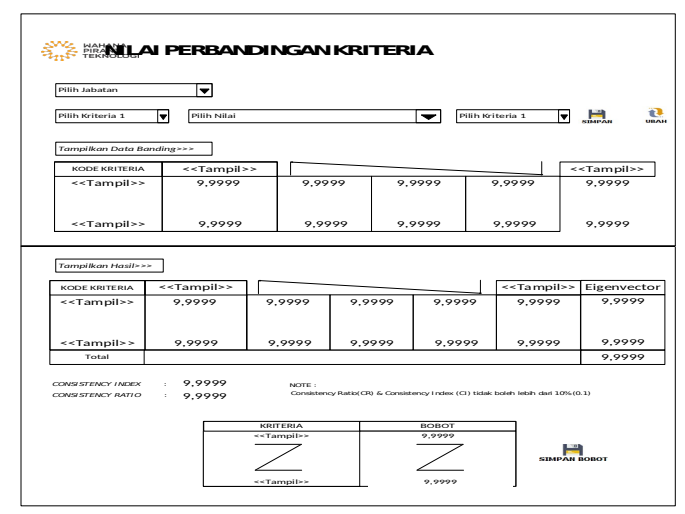

Gambar 11. Rancangan Layar Entri Nilai Perbandingan Kritorion

3) Rancangan Layar Entri Hasil Keputusan Pada rancangan layar entri hasil keputusan seperti pada gambar 12, terdapat kode jabatan dan periode sebagai parameter dalam entri hasil keputusan. Tabel nilai hasil alternatif terisi berdasarkan periode dan jabatan, form karyawan terpilih terisi dengan memilih pada tabel nilai hasil alternatif. Fungsi yang terdapat pada form ini yaitu simpan hasil keputusan.

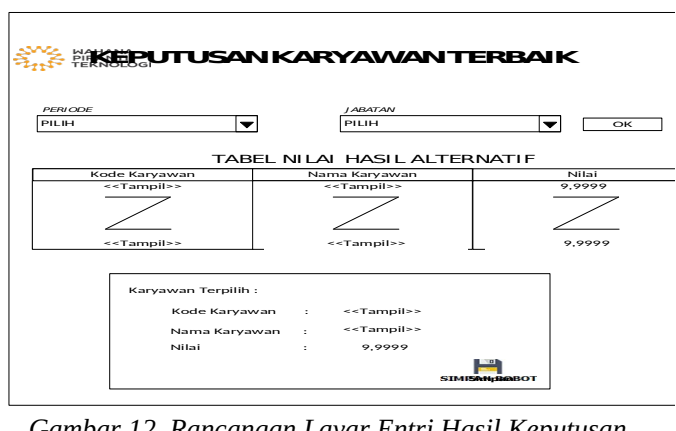

Gambar 12. Rancanaan Lavar Entri Hasil Kenutusan

4) Rancangan Layar Cetak Laporan Rangking Karywan

Pada rancangan layar cetak laporan rangking karyawan seperti pada gambar 13, terdapat kode jabatan dan periode sebagai parameter dalam pencetakkan laporan rangking karyawan. Laporan rangking karyawan akan ditampilkan dengan menggunakan tombol cetak.

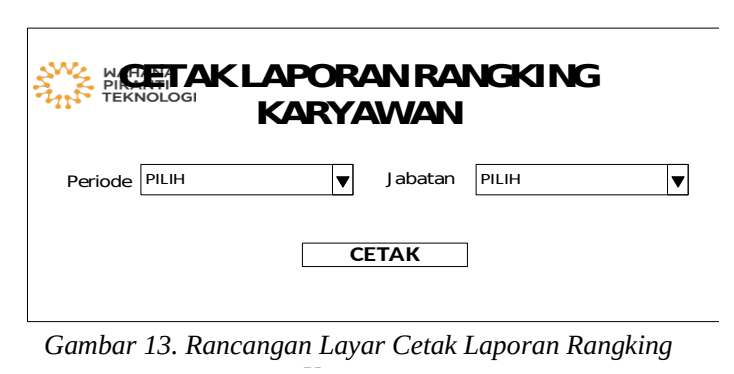

\subsection{Hasil Penelitiaan}

Penelitian pada PT. Wahana Piranti Teknologi menghasilkan bobot dari setiap kriteria yaitu pada jabatan technical kriteria Lama Bekerja 4,1\%, kriteria Presentasi 5,58\%, kriteria Project 58,76\%, kriteria Sertifikasi 21,03\%, dan kriteria Training 10,53\%. Sedangkan pada jabatan sales bobot kriteria Lama Bekerja 5,47\%, kriteria Project 29,33\% dan kriteria Achievement 65,20\%. Hasil penghitungan bobot kriteria tersebut telah diuji dengan nilai Consistency Index (CI) pada jabatan technical 0.0835 dan Consistency Ratio (CR) 0,0745. Sedangkan pada jabatan sales nilai Consistency Index (CI) sebsesar 0.0538 dan nilai Consistency Ratio (CR) sebesar 0,0928. Nilai CR pada kedua jabatan tersebut sudah konsisten karena lebih kecil atau sama dengan 0,1. Penghitungan dengan metode SAW menghasilkan perangkingan karyawan dengan nilai terbaik pada jabatan technical dimiliki oleh Ari Agus Triyono dengan nilai 0,9381, dan pada jabatan sales dimiliki oleh Meirina Hidayat dengan nilai 0,8928 .

\section{KESIMPULAN}

Dengan adanya sistem pemilihan karyawan terbaik pada PT. Wahana Piranti Teknologi, dapat membantu manajer dalam meningkatkan sumber daya manusia yang ada diperusahaan. Sistem penunjang keputusan dengan metode Analytical Hierarchy Process (AHP) dan Simple Additive Weighting (SAW) yang telah dibuat, dapat mempermudah manajer dalam mengolah nilai karyawan sesuai dengan metode yang diterapkan, mempermudah dalam mengakses data-data yang diperlukan, karena sistem yang dibangun telah terkomputerisasi yaitu berbasis desktop dan menggunkan database dalam penyimpanan data, serta dapat menghasilkan keputusan pemilihan karyawan terbaik yang lebih tepat. Informasi hasil keputusan, informasi rangking karyawan dan informasi hasil kinerja karyawan pada jabatan dan periode tertentu dapat dilihat dengan menggunkan fungsi cetak pada setiap form laporan. 


\section{DAFTAR PUSTAKA}

[1] Wulandari, N. E, "Sistem Pendukung Keputusan Penentu Karyawan (Agen) Terbaik Menggunakan Metode Analytical Hierarchy Process (AHP) (Study Kasus : Kantor Cabang AJB Bumiputera 1912 Lubuk Pakam,” Pelita Informatika Budi Darma, vol. IX(3), 2015, pp.180-181.

[2] Anto, A. G., Mustafidah, H., \& Suyadi, A, "Sistem Pendukung Keputusan Penilaian Kinerja Karyawan Menggunakan Metode SAW (Simple Additive Weighting) di Universitas Muhammadiyah Purwokerto,” JUITA, vol. III(4), 2015, P.194.

[3] Sari. F, Metode dalam Pengambilan Keputusan, Yogyakarta: Deepublish, 2018.

[4] Nofriansyah, D. \& Defit, S, Multi Criteria Decision Making (MCDM) Pada Sistem Pendukung Keputusan, Yogyakarta : Deepublish, 2017.

[5] Hasugian, H. \& Putra, E. "Sistem Penunjang Keputusan Pemilihan Pegawai Terbaik Dengan Metode AHP Dan SAW Pada PT. Sukma Jaya Mandiri,” Jurnal TELEMATIKA MKOM, vol. 9(3), 2017, p.103.

[6] Marpaung, N, Penerapan Metode Simple Additive Weighting Pada Sistem Pendukung Keputusan Untuk Menentukan Kenaikan Gaji Karyawan, JURTEKSI (Jurnal Teknologi dan Sistem Informasi), vol. IV(2), 2018, p.171. 